\title{
Feeding behavior of Frontonia leucas (Ehrenberg) (Protozoa, Ciliophora, Hymenostomatida) under different environmental conditions in a lotic system
}

\author{
Roberto Júnio P. Dias \& Marta D’Agosto
}

Departamento de Zoologia, Instituto de Ciências Biológicas, Universidade Federal de Juiz de Fora. Campus Universitário, 36036-900, Juiz de Fora, Minas Gerais, Brasil.E-mail: rjuniodias@yahoo.com.br; marta.dagosto@ufjf.edu.br

\begin{abstract}
The objective of this study was to record and describe the morphological changes and the ingestion mechanisms of Frontonia leucas (Ehrenberg, 1833) according to the food type and to relate the food ingested with the different environmental conditions in a lotic system, namely São Pedro stream, located in the municipality of Juiz de Fora, Minas Gerais, Brazil. We sampled three points on a monthly basis from August 2002 to June 2003, each of which receiving different levels of untreated sewage. We prepared culture media for the ciliate specimens containing filtered water from each point and the types of food observed inside $F$. leucas (cyanobacteria, diatoms, desmids and testate amoebas). We observed the ingestion mechanisms of $F$. leucas in vivo, under a phase contrast optical microscope, using instantaneous sampling and sequence sampling as behavior observation methods, noting the following parameters: dissolved oxygen concentration, $\mathrm{pH}$, conductivity and water temperature. We noted the F. leucas ciliates ingesting diatoms and desmids at collection point 1 and filamentous cyanobacteria, testate amoebas (Arcella and Centropyxis) and rotifers at points 2 and 3. The present work records for the first time the ingestion of testate amoebas of the genus Centropyxis by $F$. leucas. We noted five ingestion mechanisms by $F$. leucas while feeding on cyanobacteria and testate amoebas of the genus Centropyxis, three of these related to the ciliary action and two involving physical changes in the cytoplasm. For ingestion of diatoms, desmid (Closterium) and Arcella, the mechanisms involving ciliary action alone were sufficient for ingestion, since these preys are smaller than the ciliate under

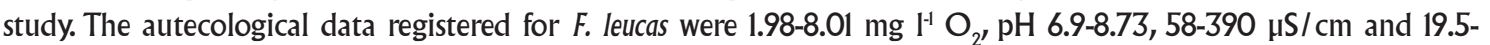
$26.2^{\circ} \mathrm{C}$, confirming its ample ecological valence.
\end{abstract}

KEY WORDS. Ciliate; polluted stream; predator; prey.

RESUMO. Comportamento alimentar de Frontonia leucas (Ehrenberg) (Protozoa, Ciliophora, Hymenostomatida) sob diferentes condições ambientais em um sistema lótico. O objetivo do presente trabalho foi registrar e descrever as alterações morfológicas e os mecanismos de ingestão em Frontonia leucas (Ehrenberg, 1833), conforme o tipo de alimento, e relacionar o alimento ingerido às diferentes condições ambientais de um sistema lótico, 0 córrego São Pedro, localizado no Município de Juiz de Fora, Minas Gerais, Brasil. Foram amostrados mensalmente, de agosto de 2002 a junho de 2003, três pontos que recebem diferentes níveis de lançamento de esgoto doméstico in natura. Foram preparados meios de cultura dos espécimes do ciliado em estudo, contendo água filtrada de cada ponto e os tipos de alimento observados no interior de F. leucas (cianobactérias, diatomáceas, desmídeas e tecamebas). Os mecanismos de ingestão de $F$. leucas foram observados in vivo, sob microscópio óptico de contraste de fase, utilizando-se como métodos de observação do comportamento a amostragem instantânea e a amostragem de seqüência. Registraram-se os seguintes parâmetros: teor de oxigênio dissolvido, pH, condutividade elétrica e temperatura da água. Os ciliados da espécie $F$. leucas foram observados ingerindo diatomáceas e desmídeas no ponto 1 de coleta e cianobactérias oscilatórias, tecamebas (Arcella e Centropyxis) e rotíferos nos pontos 2 e 3.0 presente trabalho registra pela primeira vez a ingestão de tecamebas do gênero Centropyxis por $F$. leucas. Foram observados cinco mecanismos de ingestão realizados por $F$. leucas ao se alimentarem de cianobactérias e de tecamebas do gênero Centropyxis, sendo três relacionados com a ação ciliar e dois envolvendo mudanças físicas no citoplasma. Para a ingestão de diatomáceas, desmídeas e tecamebas do gênero Arcella somente os mecanismos que envolvem a ação ciliar foram suficientes para a ingestão, uma vez que estes alimentos são menores que o ciliado em estudo. Os

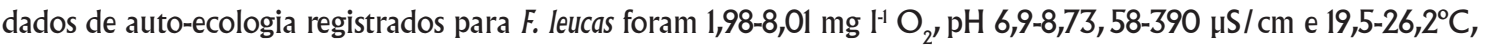
confirmando sua ampla valência ecológica.

PALAVRAS-CHAVE. Ciliado; córrego poluído; predador; presa. 
Frontonia leucas (Ehrenberg, 1833) is found in running and stagnant water throughout the year, living in sediments at depths of up to five centimeters, and also in plankton. Although it forms resting cysts, there are no reports of its occurrence in terrestrial habitats. It is rare in marshlands, estuaries and sewage treatment plants. It is a widely distributed species (FoIsSNER et al. 1999). According to BeERs (1933) and FoIsSNER et al. (1999), it feeds on bacteria and heterotrophic and autotrophic flagellates, diatoms, algae up to $50 \mu \mathrm{m}$ across, naked amoebas (Amoeba proteus Leidy 1878), testate amoebas (Arcella, Difflugia), ciliates (Coleps, Aspidisca) and even small metazoans (rotifers). DevI (1964) reported cannibalism in this species.

The most important characteristic in identifying F. leucas is its single contracting vacuole with long collecting canals and the small oral apparatus when compared to its body size (Forssner et al. 1994, 1999). GoLDSMith (1922) observed alterations in its original oval body shape according to the food ingested and the various mechanisms involved in ingesting desmids and cyanobacteria. BeERs (1933) described the ingestion mechanisms of one amoeba, A. proteus.

Frontonia leucas is included in the saprobic system, indicating environments that range from betamesosaprobic to alphamesosprobic. Because it is a eurythermic, euryoxibiontic and omnivorous species, it can be found in diverse environments and tolerates wide variations of physical and chemical parameters (FoIssNer et al. 1999).

The objective of this study was to record and describe the morphological changes and the ingestion mechanisms of F. leucas, according to the type of food, and to relate the food ingested with the different environmental conditions in a lotic system, São Pedro stream, located in the municipality of Juiz de Fora, Minas Gerais, Brazil.

\section{MATERIAL AND METHODS}

In the present study we collected monthly samples from August 2002 to June 2003 from three points along São Pedro stream in the municipality of Juiz de Fora, Minas Gerais, Brazil, in order to obtain samples with different levels of raw domestic sewage. Point 1 (UTM $=663036,7590303)$ receives a low sewage inflow, while points $2(\mathrm{UTM}=668307,7591772)$ and $3(\mathrm{UTM}=668645,7592804)$ receive high sewage loads. We obtained sediment samples using $300-\mathrm{mL}$ beakers. We then took the samples to the laboratory, placed them in Petri dishes and examined them under a stereoscopic microscope. We selected the specimens of $F$. leucas using micropipettes and observed them under an optical microscope (Olympus BX 41), taking digital photomicrographs of the specimens that showed some type of food in the cytoplasm. We then prepared cultural media of the specimens containing filtered water from each collection point and the types of food observed inside them (cyanobacteria, diatoms, desmids and testate amoebas). To observe the morphological changes and the ingestion mechanisms in vivo, we selected specimens of $F$. leucas and the foods from the culture media and transferred them to wet slides for observing living ciliates (TUFfrau 1959) and observed them under a phase contrast optical microscope. The observation techniques employed were instantaneous sampling and sequence sampling, according to AltMann (1974), as adapted for the study of protozoans by D'Agosto et al. (2003).

We monitored the physical and chemical qualities of the water at each collection point with portable equipment, recording the dissolved oxygen concentration, $\mathrm{pH}$, conductivity and water temperature. Statistical treatment of the physical and chemical data was by multivariate distance analysis (Euclidean distance).

\section{RESULTS AND DISCUSSION}

We observed the ciliates of F. leucas (Figs 1-2) ingesting filamentous cyanobacteria (Figs 3-9), testate amoebas (Arcella Ehrenberg, 1832 and Centropyxis Stein, 1857) (Figs 10-11) and rotifers (Fig. 12) at points 2 and 3 and diatoms (Fig. 13) and desmids (Closterium Nitzsch) (Fig. 14) at collection point 1. This work presents the first report of the ingestion of testate amoebas of the genus Centropyxis by F. leucas (Fig. 11), and the first record by photomicrographs of the morphological changes in F. leucas caused by the food ingested.

\section{Morphological changes}

The various types of food ingested by F. leucas cause alterations in their size and body shape (GoldsMith 1922). In the present study, there were morphological changes when the ciliates were feeding on cyanobacteria and testate amoebas of the genus Centropyxis. When the specimens fed on cyanobacteria (blue-green algae), we observed the following forms: circular (Fig. 3-5), semi-circular (Fig. 4), U-shaped (Fig. 7) and asymmetric (Fig. 8). GolDSMITH (1922) described some similar shapes after F. leucas ingested cyanobacteria of the species Oscillatoria prolifica Gomont, 1892. In the present study, we noted that the ingestion of testate amoebas of the genus Centropyxis caused a slight widening of the body (Fig. 11), as recorded by BeERS (1933) while observing the ingestion of Amoeba proteus by F. leucas. The ingestion of diatoms and desmids did not cause any morphological alterations in F. leucas.

\section{Ingestion mechanisms}

All five of the ingestion mechanisms of $F$. leucas when feeding on cyanobacteria and algae described by GolDSMITH (1922) were observed in the present work. Of these, three were related to the ciliary action: (1) pull exerted on the incoming food by the circumoral cilia, (2) movement of the ciliate in the direction of the food through the action of its own body cilia, and (3) a series of orderly changes in the position of the ciliate with reference to the food which permits the food to pass posteriorly with greater facility along the aboral surface of the ciliate. The other mechanisms involved physical changes in the cytoplasm: (4) superficial contractions of the aboral surface of the ciliate, forming tension points, and (5) cyclosis. 

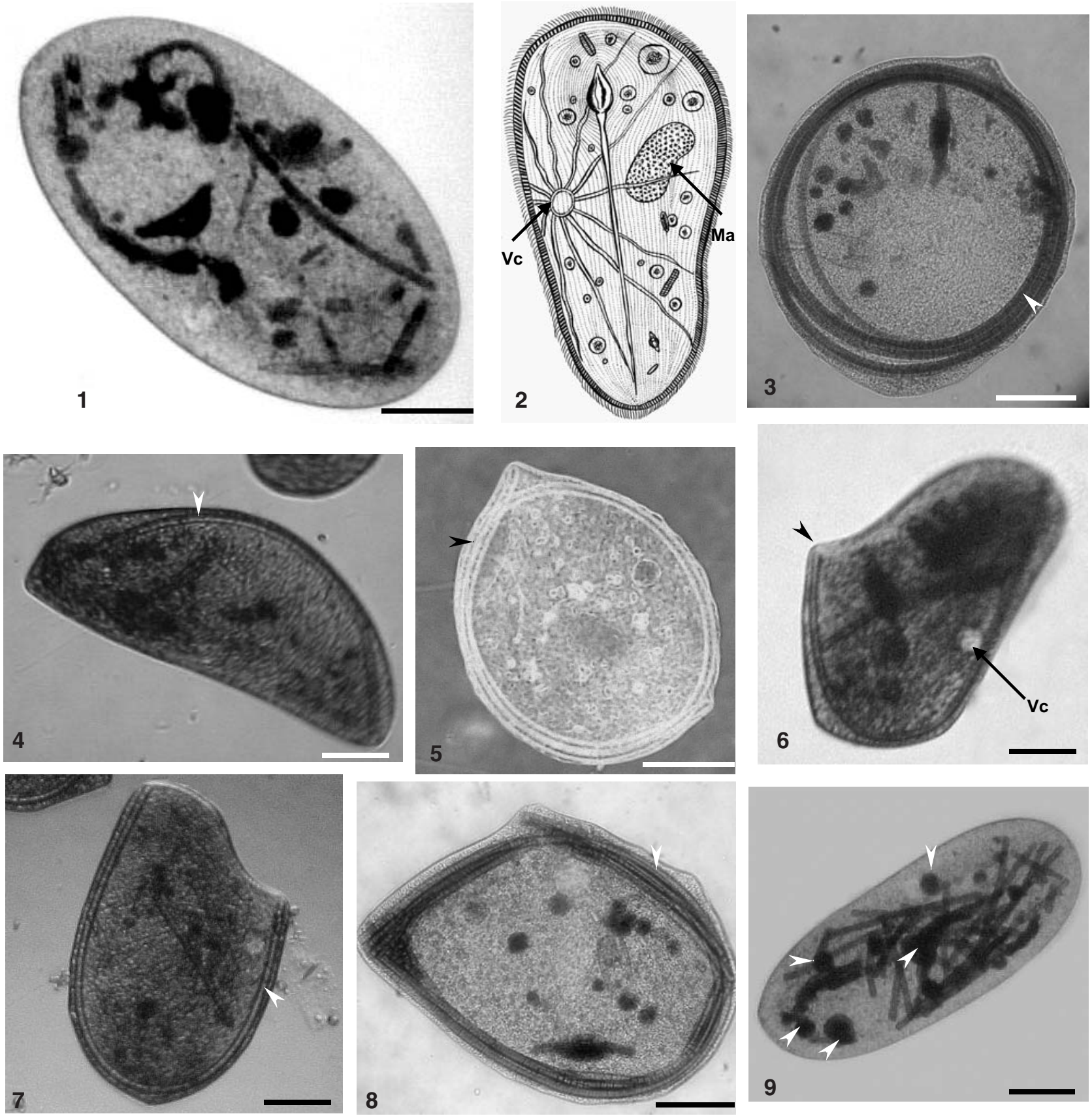

Figures 1-9. Morphological changes and ingestion mechanisms in Frontonia leucas: (1) the original oval body shape; (2) schematic drawing in vivo; (3 and 5) circular form; (4) semi-circular form; (7) U-shaped form; (6 and 8) asymmetric form;(3-5, 7-8) the arrows marks the cyanobacteria ingested; (6) formation of tension points (arrow); (9) spherical food vacuoles (arrows) containing an irregular mass. (Vc) Contracting vacuole, $(\mathrm{Ma})$ macronuclear. Bars $=50 \mu \mathrm{m}$.

We observed the five mechanisms of ingesting cyanobacteria already described by GolDSMith (1922) and BeERS (1933). We noted the formation of tension points when the specimens were ingesting cyanobacteria (Fig. 6). Although digestion is

Revista Brasileira de Zoologia 23 (3): 758-763, setembro, 2006 separate from the ingestion mechanisms, we observed the breaking-up of filamentous cyanobacteria and the formation of small spherical food vacuoles (Fig. 9) containing an irregular mass. Goldsmith (1922) mentioned this digestion step, but did not 

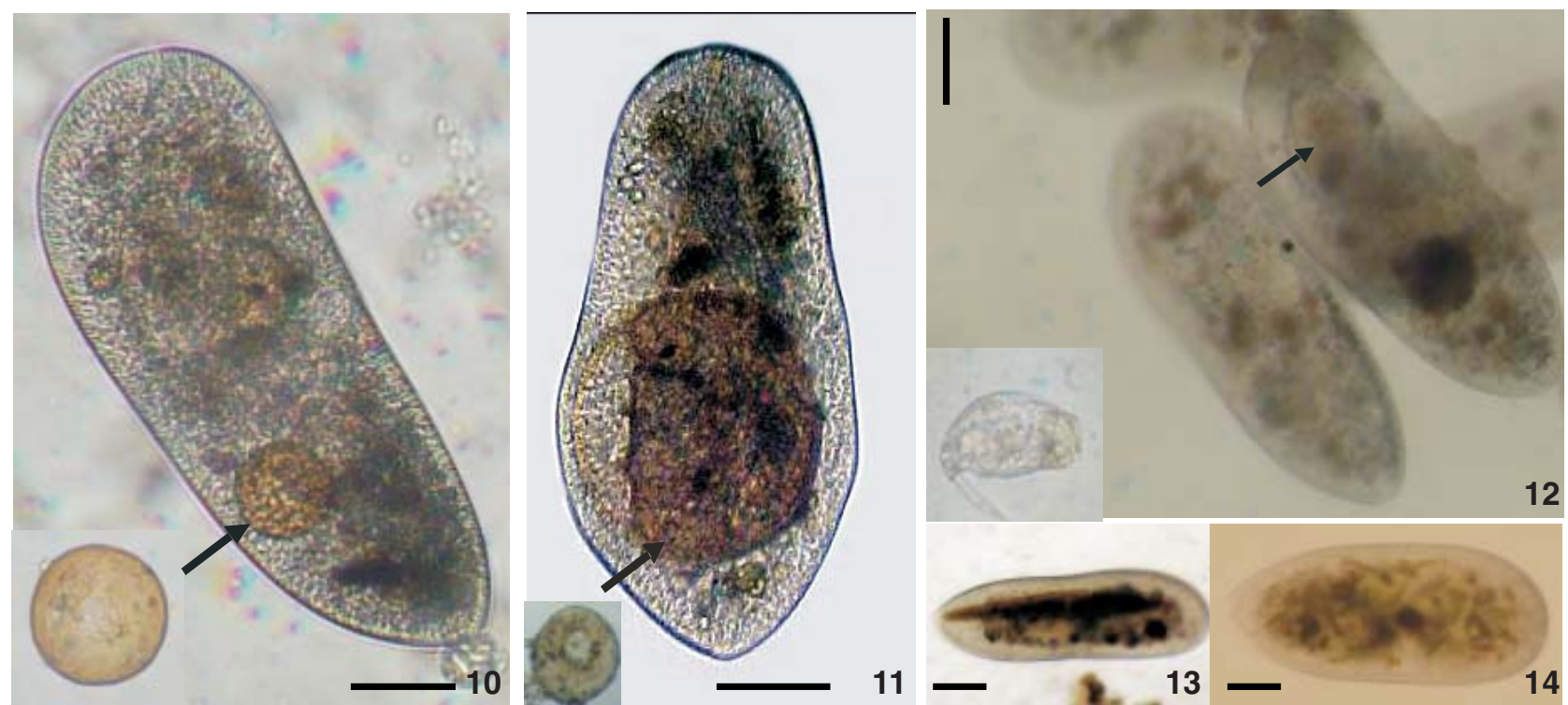

Figures 10-14. Frontonia leucas in ingesting: (10) a testate amoeba Arcella sp.; (11) a testate amoeba, Centropyxis sp.; (12) a rotifer; (13) a large desmid, Closterium sp.; (14) diatoms. Bars $=50 \mu \mathrm{m}$.

present an illustration. According to this author, the entire digestive process takes approximately six hours. In the study of the feeding behaviour of another raptorial ciliate that feeds on cyanobacteria, Pseudomicrosthorax dubis (Maupas, 1883) Penard, 1922, was reported that the mechanisms for recognizing and ingesting cyanobacteria of the genus Oscillatoria are related to the influx of $\mathrm{Ca}^{+2}$ and efllux of $\mathrm{K}^{+}$(RADEK \& HAUSMANN 1996).

We verified that the specimens in the present study, while ingesting testate amoebas, employed the same five mechanisms described by GoldsMith (1922) and confirmed by BeERs (1933) in observing the ingestion of $A$. proteus by $F$. leucas.

For ingestion of diatoms and Arcella, the three mechanisms involving ciliar action were sufficient, since these foods are smaller than F. leucas. GolDSmith (1922) reported that when the prey ingested is smaller than the ciliate, mechanisms involving physical changes in the cytoplasm are not necessary.

\section{Feeding habits and environmental conditions}

We observed the ciliates of the species F. leucas ingesting diatoms and desmids at collection point 1 and filamentous cyanobacteria, testate amoebas (Arcella, Centropyxis) and rotifers at points 2 and 3 . The availability of food is an important biotic factor that controls the distribution of protozoan populations in various ecosystems (Noland 1925, Primc 1988, PrimcHabdija et al. 1998, MADONI \& BASSANini 1999), but the omnivorous dietary habit of $F$. leucas allows it to live both in the headwaters and polluted stretches of various lotic systems, as registered in the present work and by other authors (CZAPIK 1982, Sparagano \& Grolière 1991, Packroff \& Zwick 1996, Sola et al. 1996, Madoni \& Bassanini 1999). In São Pedro stream, we noted
F. leucas at points with different raw sewage levels, in agreement with the findings of Czapik (1982), Sparagano \& Grolière (1991) and MADONI \& BASSANINI (1999).

Another factor that influences the ciliate community is the level of sensitivity of the various species of these organisms to the physical and chemical properties of the water. This factor can be explained by the specific demands of various ciliate protozoa in relation to water characteristics such as amount of dissolved organic matter, temperature, $\mathrm{pH}$, conductivity and dissolved oxygen concentration (Noland 1925, Kudo 1967, SLeigH 1988). The three sample points were different in relation to the physical and chemical characteristics (Figs 15-18), with points 2 and 3 being most similar (Fig. 19). These results confirm the high sewage loads at points 2 and 3 due to dense human occupation in the region (Fig. 19). The minimum and maximum values of the physical and chemical parameters recorded in the samples of $F$. leucas collected were: $1.98-8.01 \mathrm{mg} \mathrm{l}^{-1} \mathrm{O}_{2}, \mathrm{pH} 6.9$ $8.73,58-390 \mu \mathrm{S} / \mathrm{cm}$ and $19.5-26.2^{\circ} \mathrm{C}$, corroborating the autecological data presented by FoISNNER et al. (1999) for F. leucas in a survey article. The occurrence of $F$. leucas in environments with a wide range of physical and chemical parameters demonstrated that this species has low sensitivity to environmental variations.

Of the eleven collections at each sample point, we recorded F. leucas in eight samples from point 1 and five from points 2 and 3. MADONI \& BASSANINI (1999), taking monthly samples during one year, studied six points of the Parma River in Italy, three of them located inside a natural park, two receiving low concentrations of sewage and one high concentrations. They recorded F. leucas seven times in the set of unpolluted and low-polluted points and not at all at the point with the

Revista Brasileira de Zoologia 23 (3): 758-763, setembro, 2006 

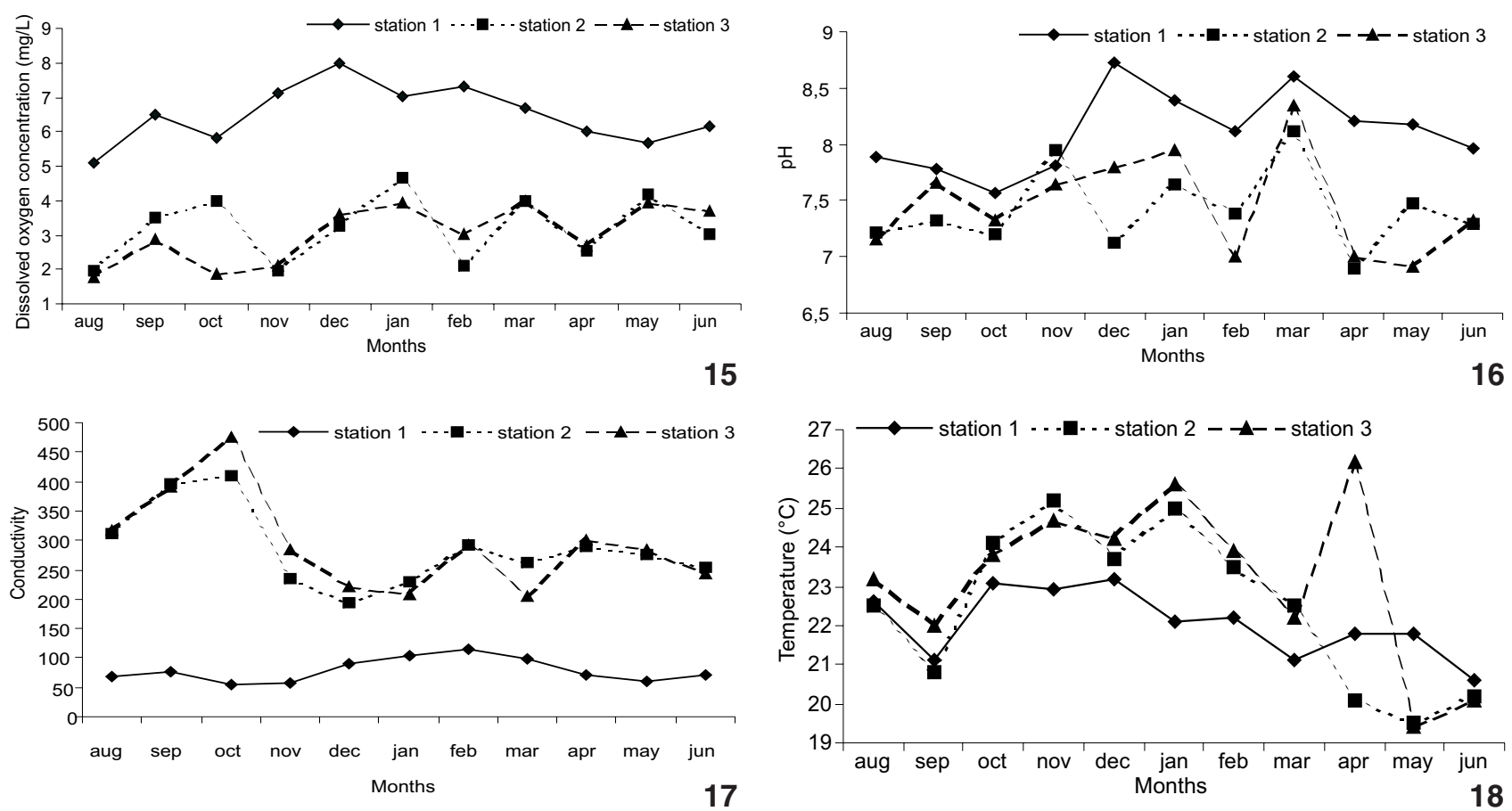

Figures 15-18. Variation of the physical and chemical qualities from three points along São Pedro stream, from August 2002 to June 2003: (15) dissolved oxygen concentration, (16) pH, (17) conductivity $(\mu \mathrm{S} / \mathrm{cm})$, and (18) temperature from three points along São Pedro stream, from August 2002 to June 2003.

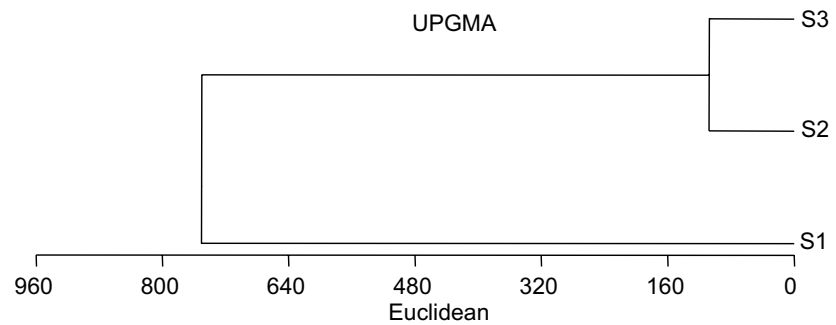

Figure 19. Dendrogram of cluster analysis, showing the similarities among stations on the basis of physycal and chemical qualities.

highest saprobic level, indicating this species' preference for alpha-beta mesosaprobic environments. The needs of these species and communities are complex and the disturbances caused by pollution can considerably alter the aquatic food chain (MADONI \& BASSANINI 1999). In oligosaprobic waters, the ciliates feed mainly on diatoms, while few feed on bacteria and cyanobacteria. As the saprobic level increases, the trophic structure is altered, causing a decrease in algivores and an increase in the number of bacterivore species. Omnivorous ciliates, such as F. leucas, become facultative bacterivores due to the abundance of bacteria in water with high sewage levels (PRIMC 1988). Because it is a species with an ample ecological valence and thus rapid ecological adaptability and wide tolerance for envi- ronmental changes, $F$. leucas has been registered at locations with different saprobic conditions.

\section{ACKNOWLEDGEMENTS}

To Roberto da G. Alves (ICB, UFJF) and Sthefane D'Avila. This research was supported by FAPEMIG.

\section{REFERENCES}

Altmann, J. 1974. Observational study of behavior: Sampling methods. Behavior, Leiden, 48: 227-265.

BeERs, D. 1933. The ingestion of large Amoeba by the ciliate Frontonia leucas. Journal of the Mitchell Society, Morehead, 17: 223-227.

CZAPIK, A. 1982. The effect of waste water on ciliate communities in the Biala Przemsza River. Acta Hydrobiologica, Kraków, 24 (1): 29-37.

D'agosto, M.T.; H.H. Santos-Prezoto \& R.J.P. Dias. 2003. Estudando o comportamento de protozoários, p. 22-28. In: K. DeLClaro \& F. Prezoto (Eds). As distintas faces do comportamento animal. São Paulo, Conceito, 276p.

Devi, V.R. 1964. Cannibalism in Frontonia leucas Ehr. Journal of Protozoology, Lawrence, 11: 304-307.

Foissner,W.; H. Berger \& F. Kohmann. 1994. Taxonomiche and ökologishe revision der ciliaten des saprobiensystem. Band III: Hymenostomata, Prostomatida, Nassulida. In-

Revista Brasileira de Zoologia 23 (3): 758-763, setembro, 2006 
formationsberichte des Bayer, Landesamtes für wasser wirschaft, Heft 1/94, 548p.

FoISSNER,W.; H. BERgER \& J. SCHUAMBURG. 1999. Identification and ecology of limnetic plankton ciliates. Munich, Bavariae State Office for Water Mannagement, Issue 3, 793p.

Goldsmith, W.M. 1922. The process of ingestion in the ciliate, Frontonia. Journal of Experimental Zoology, Hoboken, 36: 397-351.

Kudo, R.R. 1967. Protozoologia. México, Editorial Continental, $4^{a}$ ed., $905 p$.

Madoni, P. \& N. BASSANINI. 1999. Longitudinal changes in the ciliate protozoa communities along a fluvial system polluted by organic matter. European Journal of Protistology, Southampton, 35: 391-402.

Noland, L.E. 1925. Factors influencing the distribution of fresh water ciliates. Ecology, Durham, 6: 437-452.

PACKROFF, G. \& P. ZWICK.1996. The ciliate fauna of an unpolluted foothill stream, the Breitenbach, 1: qualitative aspects. Limnologica, Stechlin, 26 (3): 255-262.

PrIMC, B. 1988. Trophic relationships of ciliates Protozoa developed under different saprobic conditions in the periphyton of the
Sava River. Periodicum Biologorum, Zagreb, 90 (3): 349-353. Primc-Habdija, B.; I. Habdija \& I. Radanovié. 1998. Seazonal changes in trophic structure of periphytic ciliates in relation to discharge regime. Verhandlungen Internationale Vereiningen Limnologie, Munich, 26: 1116-1119.

Radek, R. \& K. Hausmann. 1996. Phagotrophy of Ciliates, p. 197219. In: K. Hausmann \& P.C. Bradbury (Eds). Ciliates: cells as organisms. Stuttgart, Gustav Fischer, 485p.

Sleigh, M. 1988. Protozoa and other Protists. New York, Chapman and Hall, 399p.

Sola, A.; J.F. Longás; S. Serrano \& A. Guinea. 1996. Influence of environmental characteristics on the distribution of ciliates in the River Henares (Central Spain). Hydrobiologia, Dordrecht, 324: 237-252.

Sparagano, O. \& C. Grolière. 1991. Evaluation de la qualité des eaux d'une rivièr avec les protozoaires ciliés comme bioindicateurs de pollution. Comparaison avec la physico-chimie. Hydroecologie Applique, Paris, 1: 43-62.

TuFrRAu, M. 1959. Un dispositif simple pour l'obsevation durable in vivo des microorganismes. Hydrobiologia, Dordrecht, 18 (4): 316-318.

Received in 10.I.2006; accepted in 23.VIII.2006. 